\title{
Synthetic studies towards Ambrox and analogues from coronarin-D
}

\author{
Paulo M. Imamura*, Márcia Y. Okubo, Lúcia Helena B. Baptistella \\ Instituto de Química - UNICAMP, C. Postal 6154, CEP 13.084-970, Campinas, S. Paulo, Brazil \\ *e-mail: imam@iqm.unicamp.br
}

Keywords: Ambrox, coronarin-D, terpenes

\section{INTRODUCTION}

Tetranorlabdane oxide $(\mathbf{1})^{1}$ is a synthetic substitute of ambergris and is known in the market under the trade names Ambrox $^{\circledR}$ (Firmenich), Amberlyn $^{\circledR}$ (Quest) and Ambroxan ${ }^{\circledR}$ (Henkel). ${ }^{2}$ The number of publications on this topic in the last years still demonstrate the great interest and importance of ambergris derivatives nowadays. ${ }^{3}$ As part of our current interest on organic synthesis using natural products as chiral templates, we undertook the synthesis of $A m b r o{ }^{\circledR}$ (1) from readily available coronarin-D (2), isolated from Hedychium coronarium. $^{4}$

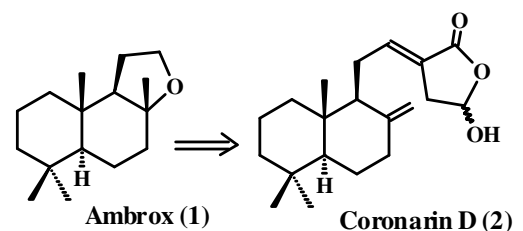<smiles>C=CC1=CCC2C(=C1)CC[C@]1(C)[C@@H](C)CCC[C@@]21C</smiles>

Ozic acid (8)

Figure 1. Structures of Ambrox (1) and coronarin-D (2)

\section{RESULTS AND DISCUSSION}

Looking at the structures of $\mathbf{1}$ and $\mathbf{2}$, we proposed manipulations on the side chain on C-9 of 2 to construct the tetrahydrofuran moiety on $\mathbf{1}$. In the first essay, an epoxidation reaction of the terminal double bond of $\mathbf{2}$ with MCPBA was tried, but it led to

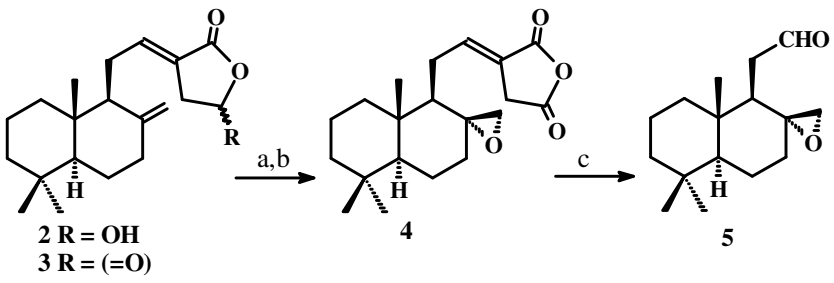<smiles>CC1(C)CCCC2(C)C1CCC1(C)C2CCCC12CCCC2(C)C</smiles>

Scheme 1. a). $\mathrm{PCC}, \mathrm{CH}_{2} \mathrm{Cl}_{2}$; b). $\mathrm{MCPBA}, \mathrm{CH}_{2} \mathrm{Cl}_{2}$; c). $\mathrm{O}_{3}$, $\mathrm{CH}_{2} \mathrm{Cl}_{2}$, then $\mathrm{P}\left(\mathrm{OCH}_{3}\right)_{3}$

an intractable mixture of compounds. Thus, the hemiketal was first oxidized with PCC and the corresponding anhydride 3, isolated in $56 \%$ yield, was treated with MCPBA. The epoxide 4, obtained in $40 \%$ yield, was submitted to an ozonolysis reaction to furnish the epoxy-aldehyde 5 . Further sequence to the synthesis of Ambrox ${ }^{\circledR}$ (1) is in progress.

Alternatively, the keto-aldehyde 7 was obtained in one step through ozonolysis of $\mathbf{2}$, but only in a modest yield of $25 \%$. The enantiomer of 7 was already prepared from ozic acid (8) and was an important intermediate used for the synthesis of ambrox analogous. ${ }^{5}$

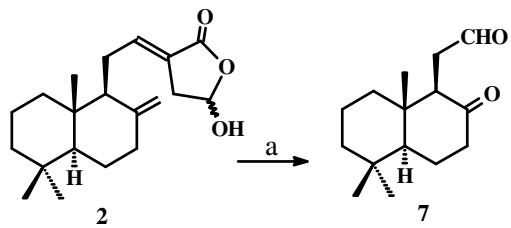

Scheme 2. a). $\mathrm{O}_{3}, \mathrm{CH}_{2} \mathrm{Cl}_{2}$, then $\mathrm{P}\left(\mathrm{OCH}_{3}\right)_{3}$

\section{CONCLUSION}

Coronarin-D (2), the major constituent of the rhizome extract of Hedychium coronarium showed to be a suitable starting material for the synthesis of ambergris type odorants. The yields presented here still need to be optimized, but the intermediates 5 and 7 represent versatile synthons for ambrox analogous.

\section{ACKNOWLEDGEMENTS}

We thank FAPESP and CNPq-PIBIC for financial support.

\section{REFERENCES}

${ }^{1}$ Sell, C. Chem. Ind. 1990, 20, 516.

2 Stoll, M.; Hinder, M. Helv. Chim. Acta 1950, 33, 1251., ibid 1308.

${ }^{3}$ For recent publications see: Xie, YP; Li, BG; Luo, YG, Hen, X.Z., Zhang, G.L. Helv. Chim. Acta 2008, 91, 734.

Okubo, M.Y., Imamura, P.M., Baptistella, L.H.B., unpublished results.

${ }^{5}$ Giacomini, R. A., Miranda, P. C. M. de L., Baptistella, L. H. B., Imamura, P. M. Arkivok 2003, Part X, 314 